\title{
MORPHOLOGICAL DEVELOPMENT OF THE RIF AND THE ENGELSMANPLAAT, AN INTERTIDAL FLAT COMPLEX IN THE FRISIAN INLET, DUTCH WADDEN SEA
}

\begin{abstract}
Z.B. Wang ${ }^{1}$ and A.P. Oost ${ }^{2}$
The Rif and the Engelsmanplaat form together a supra- to intertidal flat-complex at the fringe of the ebb-tidal delta and the back barrier area in the Frisian Inlet, located between the Dutch Wadden Sea Islands Ameland and Schiermonnikoog. The complex divides the Frisian Inlet into the Pinkegat Inlet in the west and the Zoutkamperlaag Inlet in the east. During the last decades the Engelsmanplaat has been suffering from serious erosion. This paper presents a study meant to find the causes for the recent erosion, especially to answer the question if the erosion is related to the human interferences in the area. The study is based on literature survey, data analysis and modelling of hydrodynamic processes. It is concluded that the recent erosion fits into the pseudo-cyclic development of the intertidal flat complex. However, the period of erosion may have been longer than normal and the rate of erosion may have been higher than normal. It is also concluded that such abnormal development is probably effects of the closure of the Lauwerszee in 1969 and not due to land subsidence caused by gas mining.
\end{abstract}

Keywords: Intertidal flats, Wadden Sea, Land subsidence, Closure, Morphology, Long-term development

\section{INTRODUCTION}

The Rif and the Engelsmanplaat form together a supra- to intertidal flat-complex at the fringe of the ebb-tidal delta and the backbarrier area in the Frisian Inlet, located between the Dutch Wadden Sea Islands Ameland and Schiermonnikoog (Figure 1). The complex divides the Frisian Inlet into the Pinkegat Inlet in the west and the Zoutkamperlaag Inlet in the east. Such intertidal flats in the Wadden Sea are ecologically very valuable and form an important element of the unique geomorphology of the Wadden Sea, which became a World Heritage Site in 2009.

With a tidal range of approximately $2 \mathrm{~m}$ the Frisian Inlet belongs to the meso-tidal inlets. The mean significant wave height is about $0.7 \mathrm{~m}$. According to the hydrodynamic classification of Hayes (1979) the inlet belongs to the type mixed energy, tide dominant. Sediment in the system consists mainly of fine sand although locally mud also occurs on the inter-tidal flats.

During the last decades the intertidal flat Engelsmanplaat has been suffering from serious lowering. Figure 2 shows a photo taken on the Engelsmanplaat. The small house in the picture is used for observing birds. The lower part of the stair structure was added later when it became necessary for accessing the house because of the lowering of the bed level. Question arises what has caused this serious erosion problem. One of the concerns is that the problem is caused by the land subsidence due to the gas mining on the Ameland Island since 1986. The land subsidence results in locally a relative sea-level rise rate of more than 1 meter per century, which is about the critical sea-level rise rate at which the sedimentation will no more be able to keep pace with and the tidal basin will drown on the long-term (van Goor et al., 2003). This concern was the initial motive of the present study. The objective of the study is to find out the causes of the observed lowering of the Engelsmanplaat. The following research questions are formulated: (1) Is the observed lowering natural or caused by human interference? (2) Which human interferences have possibly influenced the observed development? To answer these questions we first review the historical development of the Frishian Inlet and in particular the Engelsmanplaat by literature survey and analysis of available field data. By doing this the possibly abnormal development and the human interferences which can possibly have caused the abnormal development are identified. Then the results of process-based modelling are used to test in how far the identified human interferences influence the physical development relevant for the abnormal development.

\footnotetext{
${ }^{1}$ Deltares \& Faculty of Civil Engineering and Geosciences, Delft University of Technology, P.O. Box 177, $2600 \mathrm{MH}$ Delft, The Netherlands

${ }^{2}$ Deltares \& Department of Physical Geography, Faculty of Geosciences, Utrecht University, P.O. Box 80.115 3508 TC Utrecht The Netherlands
} 


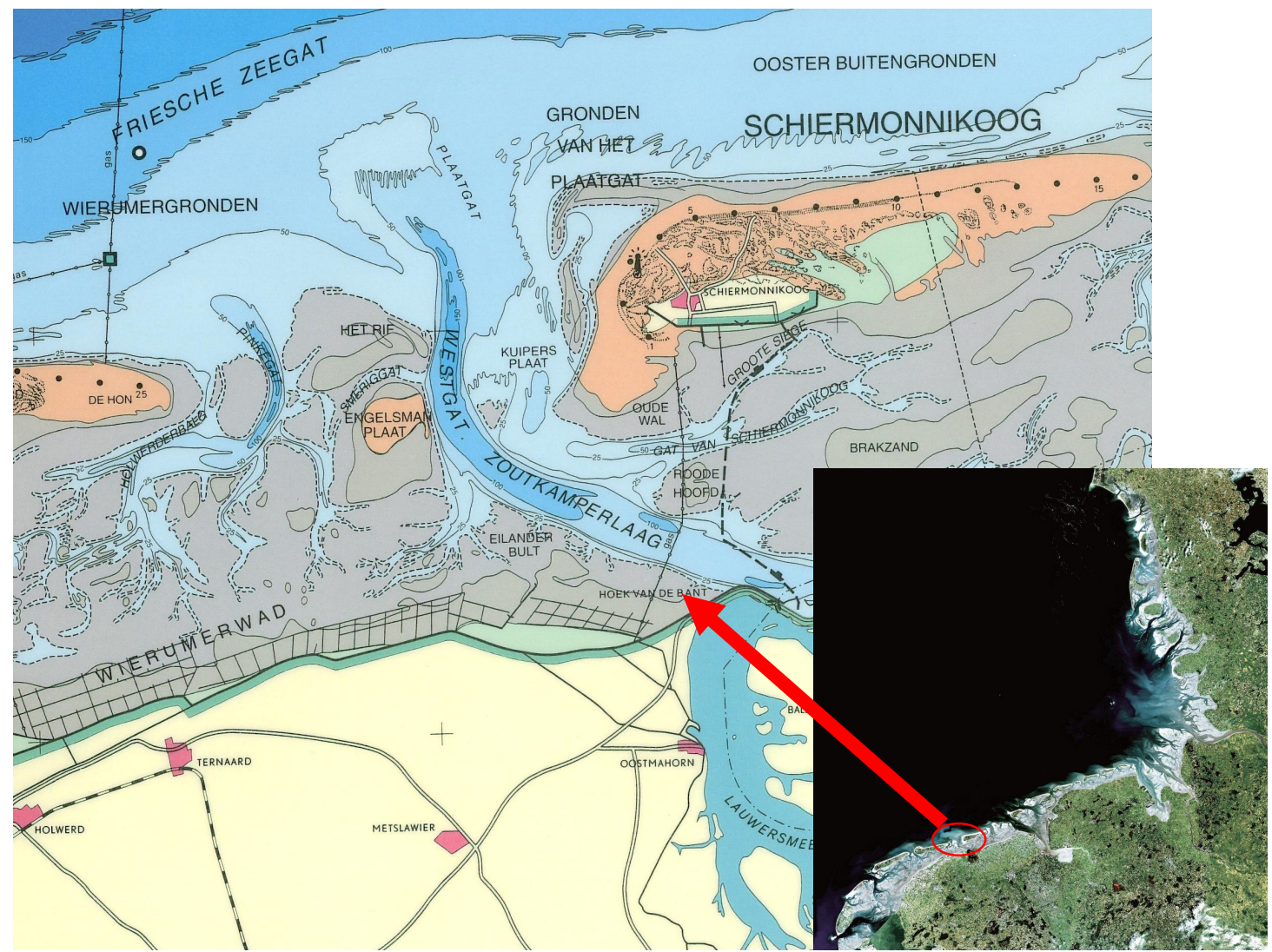

Figure 1. Study area.

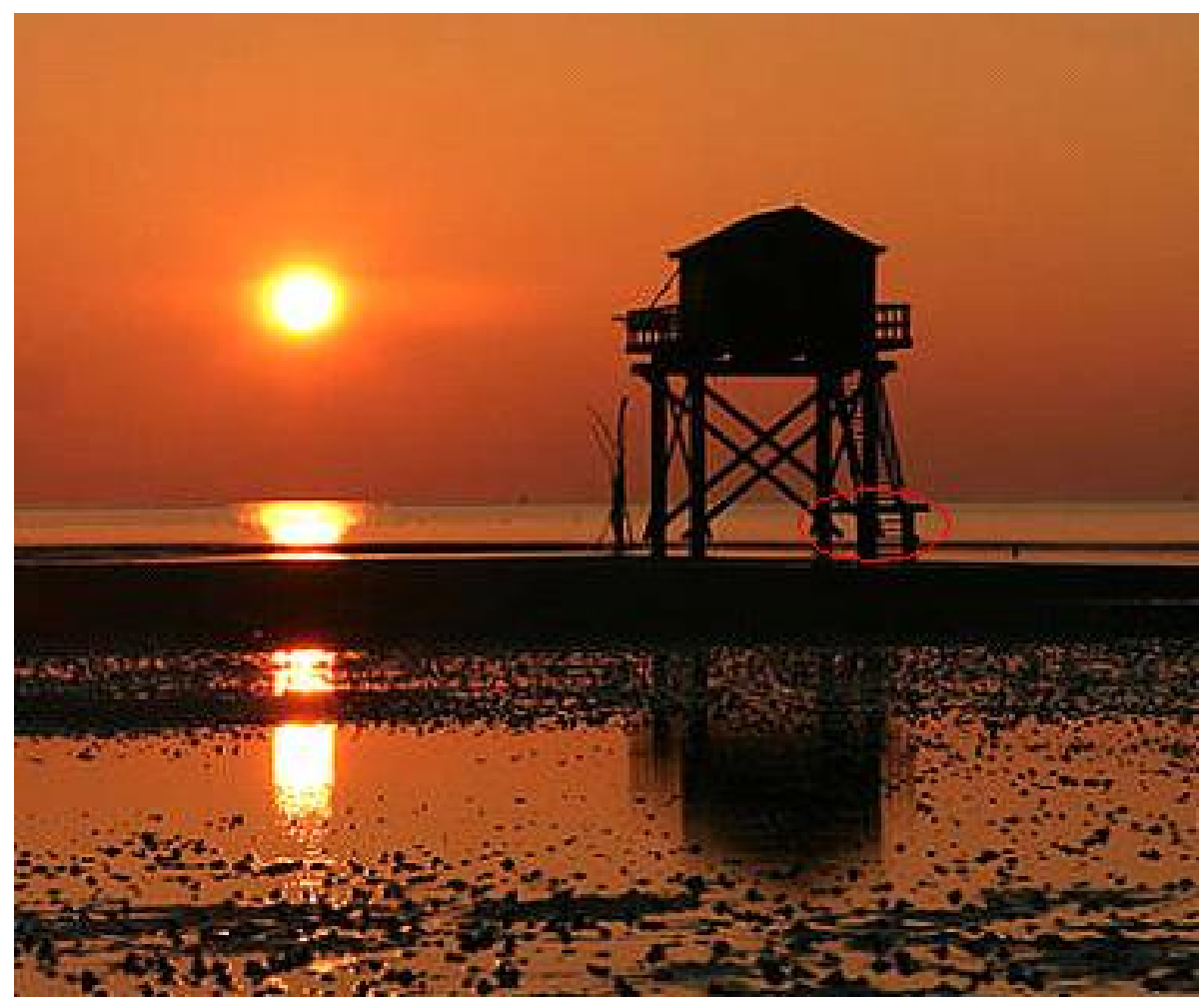

Figure 2. Photo taken on the Engelsmanplaat. The lower part of the stair structure (indicated by the red circle) was later added when it became necessary to reach the small house for bird observatory. 


\section{HISTORICAL DEVELOPMENT}

The historical development of the Frisian Inlet until 1991 was extensively described by Oost (1995). Based on historical material and bathymetry data he made a reconstruction of the development of Pinkegat, Zoutkamperlaag and Engelsmanplaat since 1300. The reconstruction reveals that the development of Engelsmanplaat shows two consistent behaviours, viz. a trend of erosion from the West side and a more or less cyclic behaviour.

Due to the erosion from the west side the width of the Engelsmanplaat decreased from $7.1 \mathrm{~km}$ in 1832 to $2.2 \mathrm{~km}$ in 1991 (Oost 1995), see Figure 3. The rate of erosion is decreased in time, but the pressure of erosion from the west side is still present. This is because of the slow migration of the Wadden Sea system from west to east. Recently the defence of the western heads of the Islands may have slowed down this process.

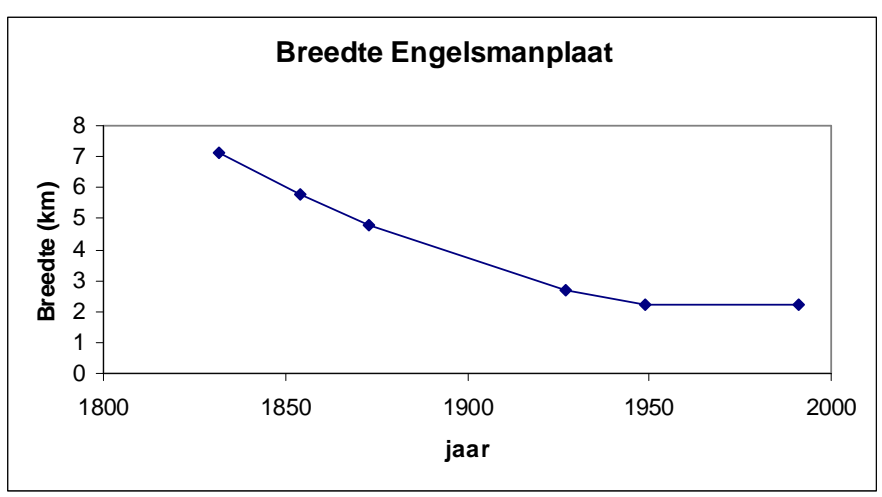

Figure 3. Historical development of the width of Engelsmanplaat (East-West direction).

The Engelsmanplaat has been a high area for a long time (Oost, 1995). In the last five centuries large supra-tidal sand banks had been developed north of the Engelsmanplaat. This has caused a more or less cyclic behaviour of the system. The sand bank is created by waves and tidal flow with sand from the ebb-tidal deltas of the Pinkegat and the Zoutkamperlaag and is separated from the Engelsmaplaat by a connecting channel. After its generation the sand bank grows to a supra-tidal sand body, and migrates to the south. The sand bank and the connecting channel block the sand transport to the Engelsmanplaat, causing erosion on this intertidal flat. After some time the connecting channel dissapears and the supra-tidal sand bank merges with the Engelsmanplaat. Every time (about once in in 100 year) when this happens, the Engelsmanplaat suddenly increases itself in area as well as height. Then this intertidal flat starts eroding again due to the generation of a new channel on the north side, and the cycle starts again. In most of the time within the cycle the Engelsmanplaat shows thus erosion.

At present the supra-tidal sand bank north of the Engelsmanplaat is called the Rif. This sand bank is now separated from the Engelsmanplaat by the connecting channel the Smeriggat. From the description above it becomes clear that these three morphological elements should not be considered separately but should be considered together as a system. Because the Rif is now separated from the Engelsmanplaat by the Smeriggat it is now in a phase of erosion on the Engelsmanplaat within the cyclic development of this system. According to Oost (1995) the Engelsmanplaat has been lowering since 1970.

Oost (1995) predicted that the Rif would merge with the Engelsmanplaat within a short term, and the Smeriggat would disappear as a channel. However, this has still not happened until now (2010). The degradation of the Smeriggat channel seems thus to be delayed.

In summary:

- The Engelsmanplaat shows a long-term trend of erosion from the west side, decreasing its width in time.

- The Engelsmanplaat shows a pseudo-cyclic development and it is now in a erosion phase within the cycle.

- The Engelsmanplaat has been lowering since 1970.

- The disappearance of the connecting channel Smeriggat seems to be delayed. 


\section{RECENT DEVELOPMENT AND HUMAN INTERFERENCES}

Two human interferences in the Frisian Inlet have been identified, which possibly can have influence on the development of the Rif-Engelsmanplaat complex, i.e. the closure of the Lauwerszee and gas mining.

The Lauwerszee used to be a part of the tidal basin of the Frisian Inlet, connected to the Zoutkamperlaag, but is closed in 1969 and became a fresh water lake. The closure has decreased the basin area of the Frisian Inlet by about one third. This has caused significant morphological changes. Erosion of the ebb-tidal delta and sedimentation of the channel in the basin of Zoutkamperlaag are the most pronounced changes observed (Stein, 1982, Oost, 1995). Figure 5 shows the changes of the ebbtidal deltas and the tidal basins of the two inlets, derived from the bathymetric data available since 1927. The definition of the four areas is accoroding to Oost (1995), see Figure 4.

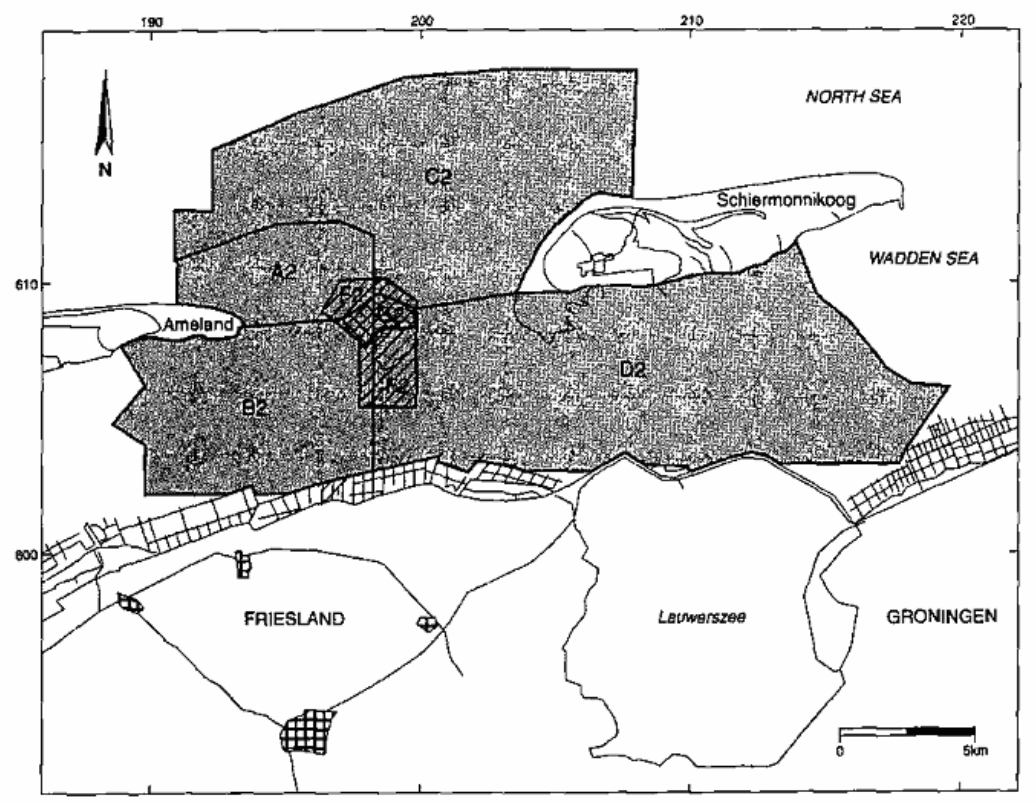

Figure 4. Considered areas for calculating sedimentation erosion amounts (Oost, 1995).
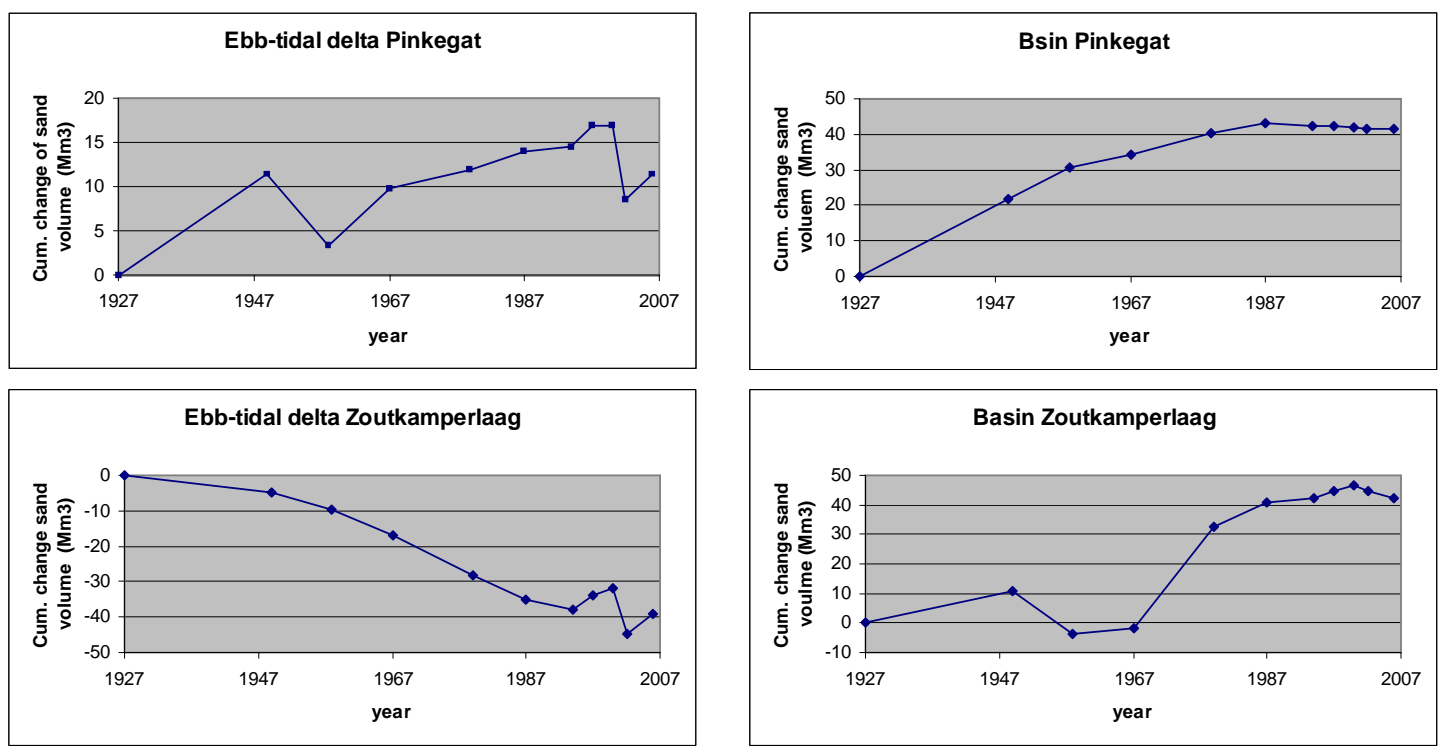

Figure 5. Cumulative change (increase = sedimentation) in the various areas as shown in Figure 4. 
Since 1986 mining of natural gas has been taking place on the Island Ameland, western of the inlet. Especially in the Pinkegat inlet land subsidence has been taking place since then. Figure 6 shows the expected land subsidence in 2040 due to gas mining on Ameland since 1986 and gas mining under Wadden Sea started recently. The maximum subsidence is $30-40 \mathrm{~cm}$. These two interferences will be considered in order to see if they can have caused the possible disturbances in the development of the Rif-Engelsman complex.

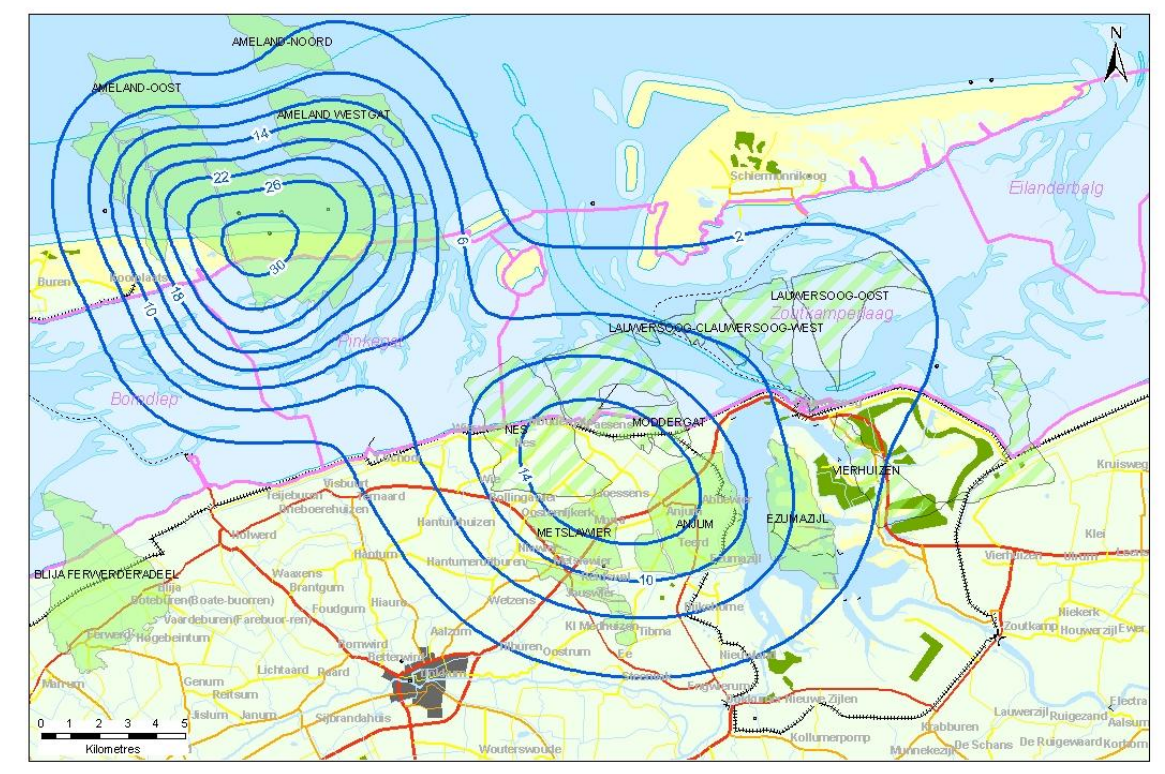

Figure 6. Contours of predicted land subsidence in 2040, in $\mathrm{cm}$.

Further all the available data have been depicted (two examples are shown in Figure 7) in contour maps and analysed to investigate the morphological changes. The following relevant observations are made:

- The connecting channel Smeriggat still separates the Engelsmanplaat and the Rif from each other. Also the Lidar data taken in March 2010 (Figure 8) show that this is still the situation. The prediction of Oost (1995) that the Rif and the Engelsmanplaat will join together within short-term has not came true for the time being. Sedimentation does take place in this channel but very slowly. De bottom of the channel is now at about 1.5 to 2 m under NAP (about mean sea level). As the development of the system is not strictly cyclic, the exact time of the joining between the Rif and the Engelsmanplaat cannot be given. However, this seems to be delayed with respect to the expectation.

- Erosion is still taking place on the Engelsmanplaat. This agrees with the theory of Oost (1995): erosion will continue as long as the Rif and the Engelsmanplaat are separated from each other. A possible deviation from the normal seudo-cyclic behaviour is that the erosion rate is higher.

- It is noticed that the tidal watershed behind the Engelsmanplaat has moved to the west since 1970. This tidal watershed can be considered as the boarder between the tidal basin of the Pinkegat inlet and that of the Zoutkamperlaag inlet. In 1970 the tidal watershed was around the middle of the Engelsmanplaat and has a more or less North-South orientation. Nowadays it is shift to the west and it has more a Northeast-Southwest orientation (Figure 8). The effect is that the basin of the Zoutkamperlaag inlet is enlarged at the cost of the Pinkegat inlet. 

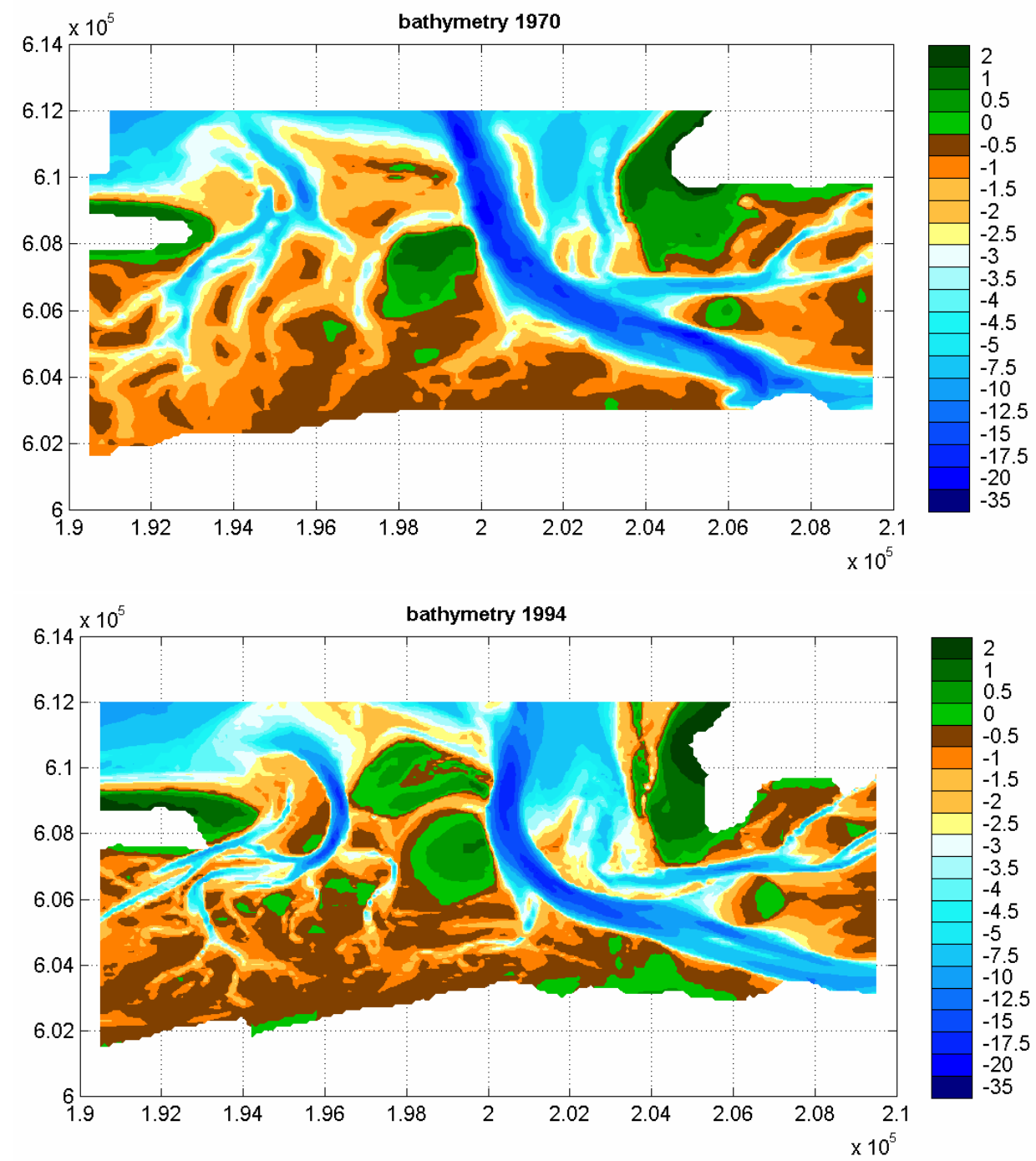

Figure 7. Measured bathymetry.

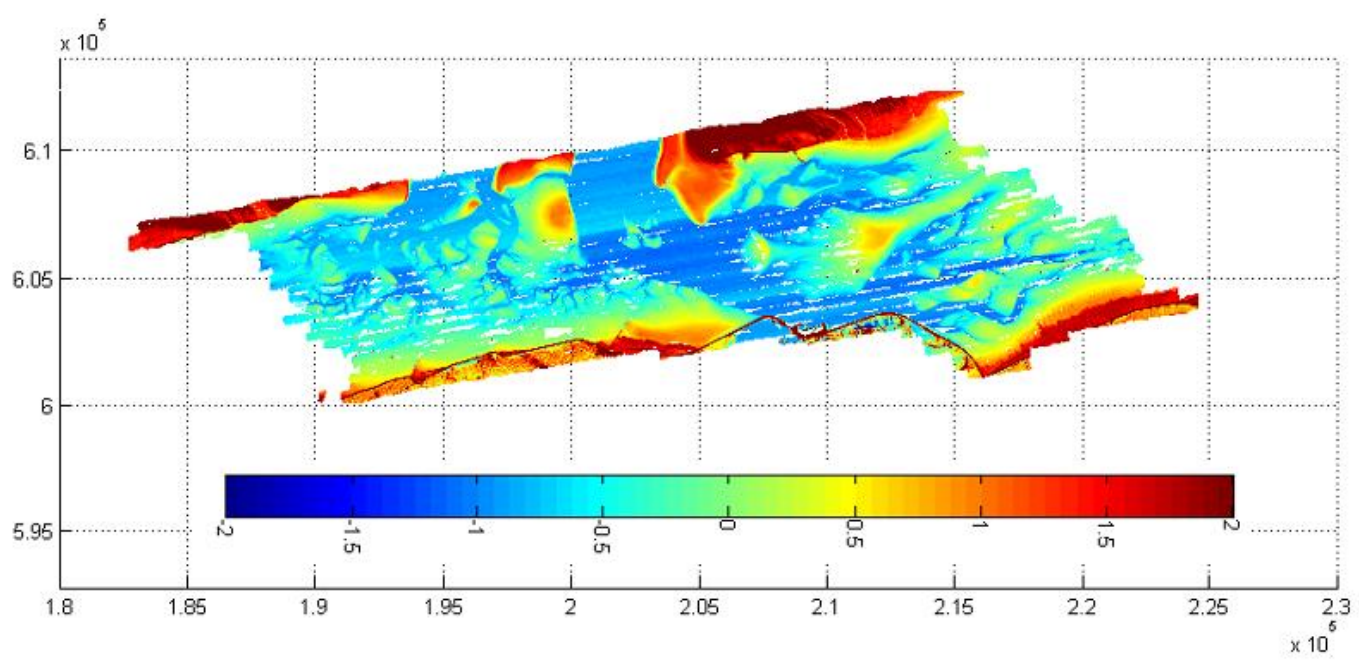

Figure 8. Lidar data from March 2010. 


\section{PROCESS MODELLING}

From the literature survey and data analysis it becomes clear that two aspects of the development of the intertidal flat-complex Rif-Engelsmanplaat may be influenced by the human interferences: The merging between the Rif and the Engelsmanplaat may be is delayed and the erosion on the Engelsmaplaat may be is accelerated. It also becomes clear that two human interferences need to be considered, viz. the closure of the Lauwerszee in 1969 and the gas mining causing land subsidence since 1986.

Process-based modeling is used to examine the influence of the two human interferences on the two aspects of the development of the intertidal flat-complex. Existing model results are revisited first before additional modeling is carried out. Here we have chosen to concentrate on the modeling of hydrodynamic processes and no long-term morphodynamic modeling has been carried out. Despite of the enormous progress in morphodynamic modeling for tidal basins during the last decades (Wang et al, 1995, Hibma et al, 2003, Van der Wegen et al, 2008, Dastgheib et al, 2008) development of such a inter-tidal flat-complex can still not be simulated in detail. Further we argue that the impact on the morphological development must via some influence on the relevant hydrodynamic processes. Therefore it is possible to answer the research questions in the present study by evaluating the impacts of the considered human interference on the relevant hydrodynamic processes.

The Rif and the Engelsmanplaat will merge with each other when the tidal channel Smeriggat between them will be closed by sedimentation. The development of such a connecting channel is closely related to the water level difference between the two ends of the channel. (Van Veen et al, 2005). A human interference can influence the development of the channel if and only if the interference has significant influence on the water level in the surrounding of the channel. Therefore the influence of the two interferences on the possibly delayed closure of the Smeriggat can be investigated by evaluating their influence on the water level.

Sedimentation-erosion on an intertidal flat is the results of channel-flat interaction. Tidal flow is responsible for transporting sediment from the channel to the flat causing sedimentation. Wind waves are responsible for erosion on the flat causing sediment transport from the flat to the channel together with tidal flow. The height of the flat is in equilibrium when these two processes balance each other. When the balance between the two processes is disturbed e.g. serious erosion of the intertidal flat can take place as reported by Mulder and Louters (1994) for the Eastern Scheldt after the construction of the Strom Surge Barrier (see also De Bok, 2001). The relevant processes for influencing the erosion rate on the Engelsmanplaat are thus flow velocity in the surrounding channels and bed shear stress on the flat cause by tidal flow and wind waves.

The effects of the closure of the Lauwerszee have been extensively studied (Stein, 1991, Oost, 1995, Wang et al., 1995). Figure 9 shows the model results by Wang et al (1995) concerning the influence of the closure on the water level, flow velocity and sediment concentration at a station in the Zoutkamperlaag close to the Rif-Engelsmanplaat complex. The closure has significantly decreased the size of the tidal basin. As a consequence it has noticeable influence on the water level and substantial influence on the magnitude of the flow velocity in the tidal channel Zoutkamperlaag east of the Engelsmanplaat. Decrease of the flow velocity in the channel means less sediment transport from the channel to the intertidal flat. 

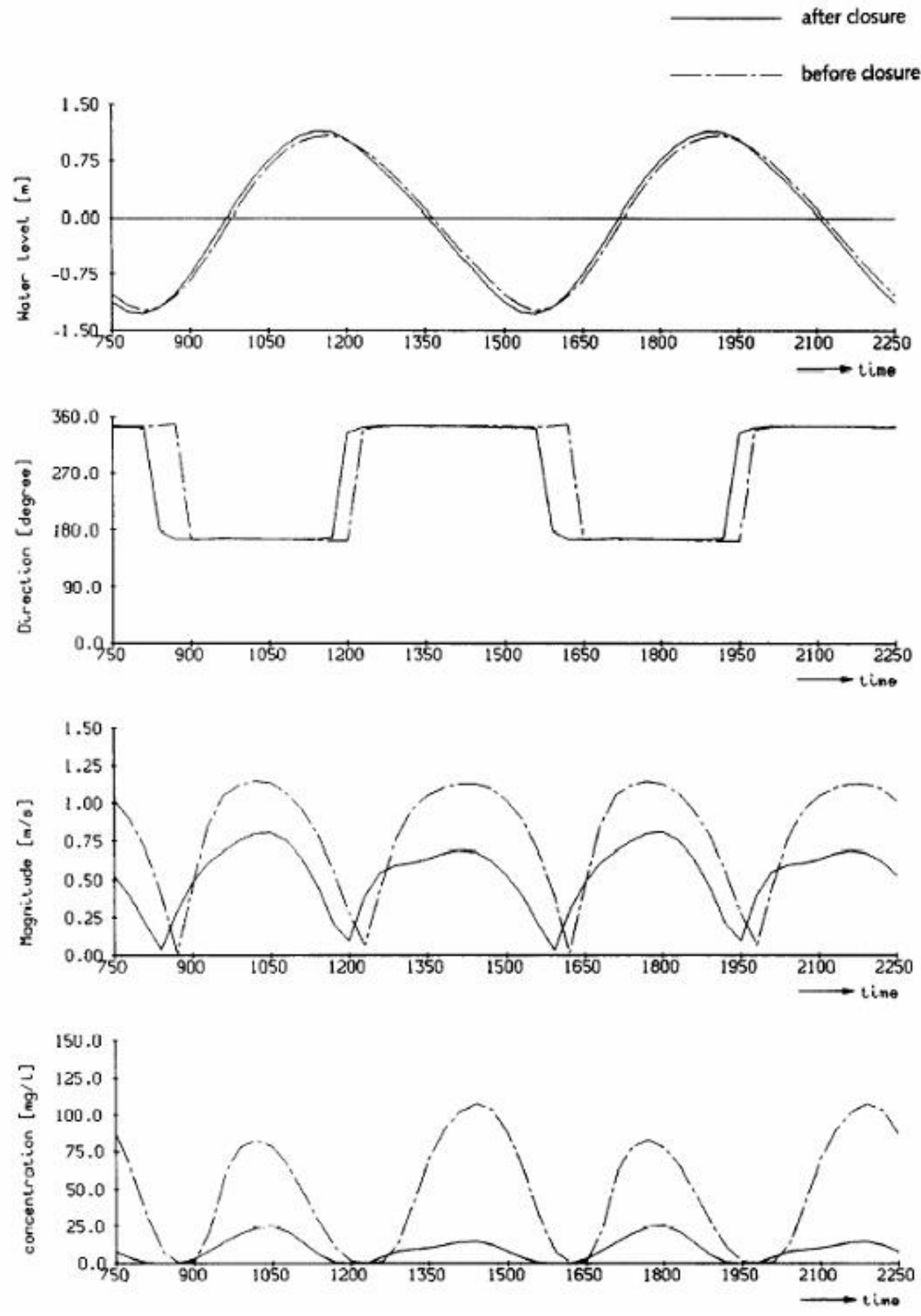

Figure 9. Influence of the closure of Lauwersezee on hydrodynamics and sediment transport (After Wang et al, 1995). 


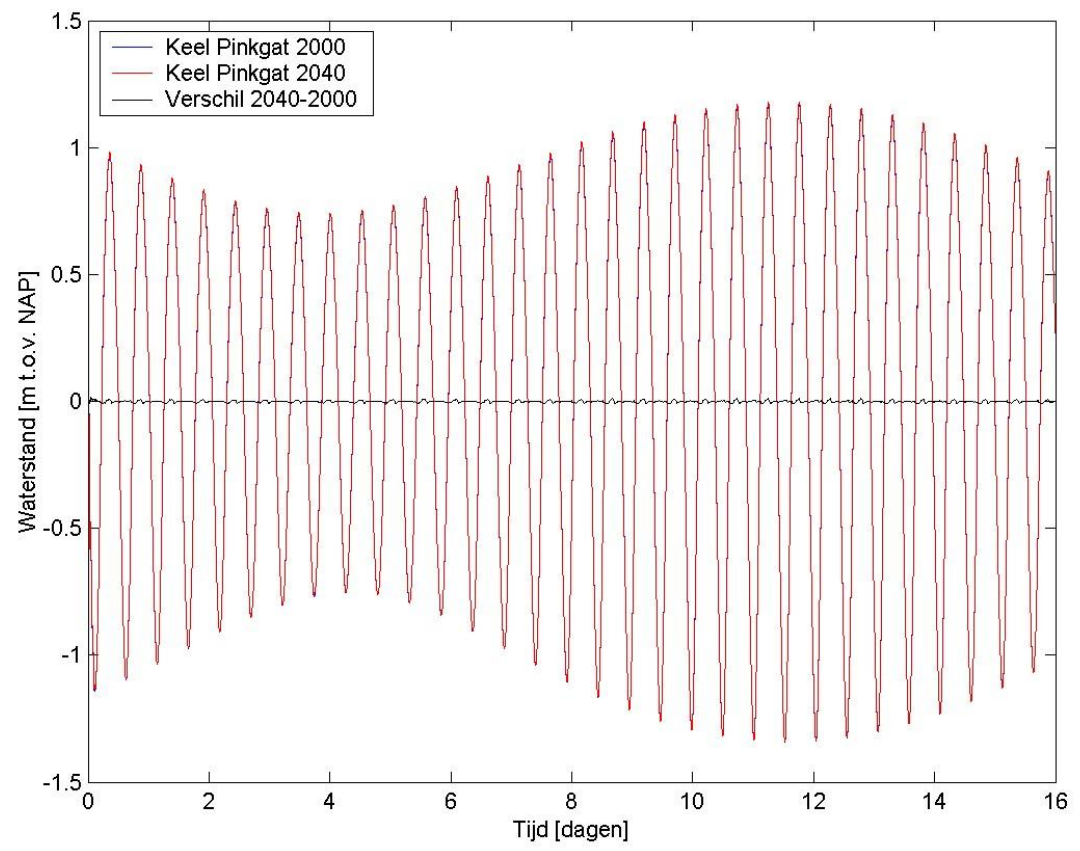

Figure 10. Influence of land subsidence due to gas mining on the water level.

The effects of land subsidence due to gas mining on the tidal flow have also been simulated before in the EIA study for the new gas mining under Wadden Sea (Wang and Eysink, 2005). The results of two simulations are shown in Figure 10 and 11, one with the measured bathymetry in 2000, and the other with the same bathymetry but then corrected with the expected land subsidence in 2040, i.e. the final subsidence. In this way the effects of the land subsidence are exaggerated. Nevertheless the influence on the water level is not noticeable (see Figure 10). The model results suggest thus that the land subsidence cannot have significant influence on the development of the Smeriggat channel. Figure 11 shows the difference between the simulated magnitudes of flow velocities from the two model runs. The differences at maximum flood as well as at maximum ebb are shown. The land subsidence appears to increase the magnitude of the flow velocities, although the increase is relatively small $(<0.1 \mathrm{~m} / \mathrm{s})$. This is due to the fact that the tidal prism is increased due to the land subsidence on the inter-tidal flat. The increased flow velocity has an increasing effect on the sediment transport from channels to intertidal flat, causing sedimentation rather than erosion on the flat.

In order to investigate the influence of the land subsidence on the bed shear stress under combined action of tidal flow and wind waves additional simulations with flow-wave interaction have been carried out. Figure 12 shows the results around the Rif-Engelsmanplaat complex of two simulations, one with the 2000 bathymetry, and the other with the same bathymetry but then corrected with the expected land subsidence in 2040. The effect of the land subsidence is hardly visible in the figure, indicating that the land subsidence does not influence the hydrodynamic processes responsible for the erosion of the intertidal flat significantly. 

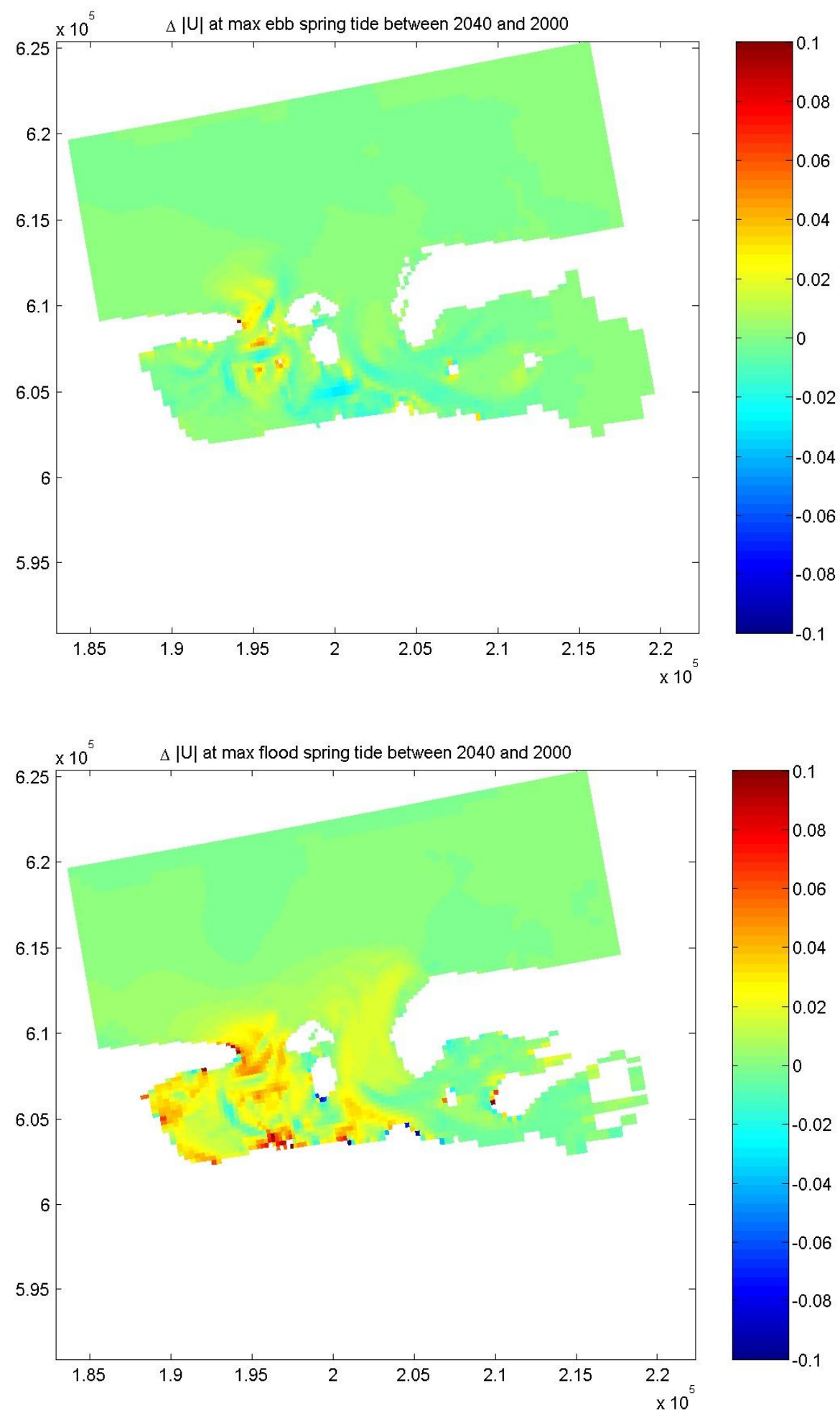

Figure 11. Effect of land subsidence due to gas mining on the magnitude of tidal flow velocity. 

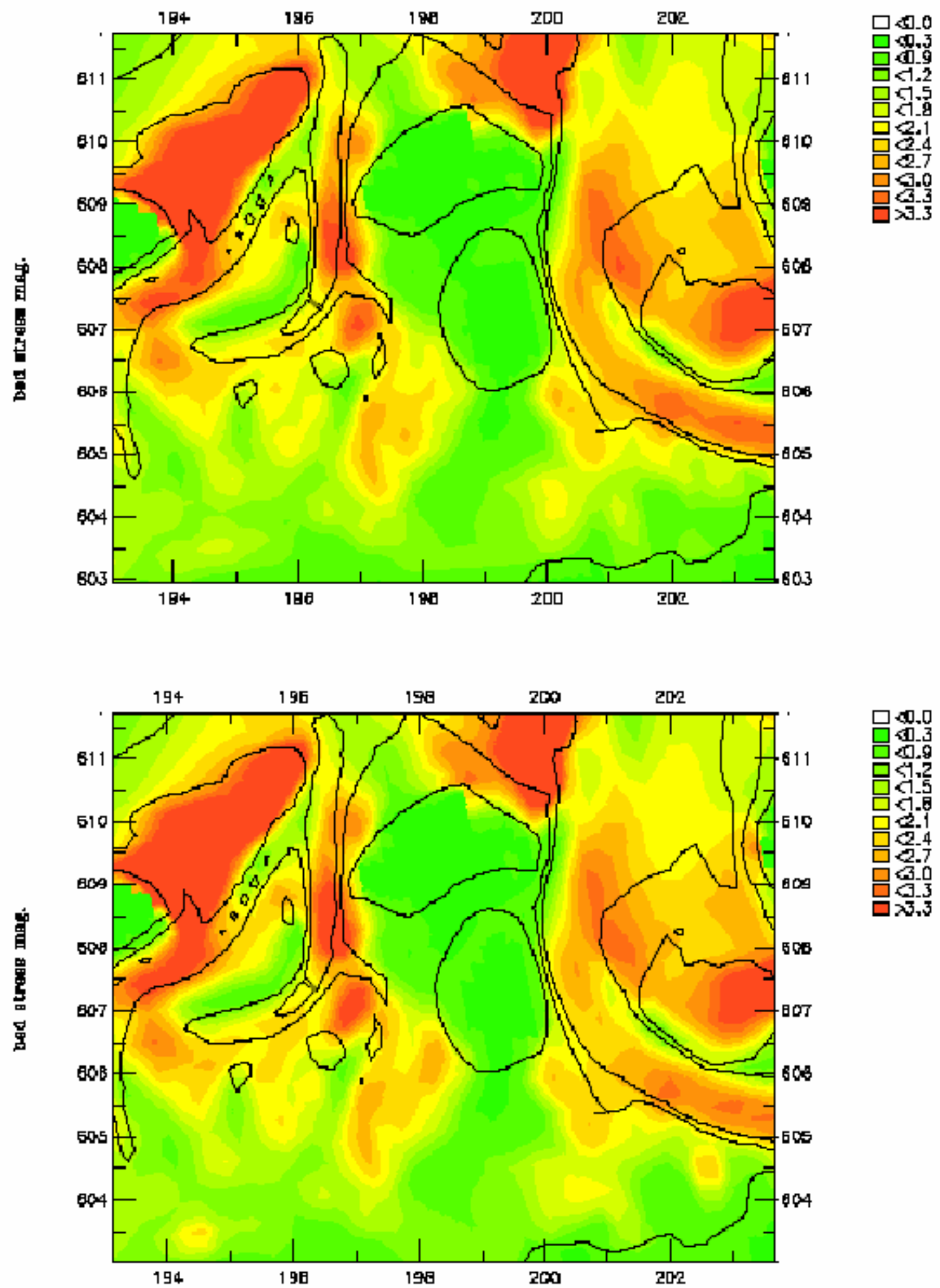

Figure 12. Computed bed shear stress under combined action of tidal flow and waves. Upper panel: without land subsidence, lower panel: with land subsidence.

\section{CONCLUSIONS}

The objective of the present study is to find out the causes of the observed lowering of the Engelsmanplaat. The research questions to be answered are: (1) Is the observed lowering natural or caused by human interference? (2) Which human interferences have possibly influenced the observed development? 
Literature survey learned that the development of the Engelsmanplaat shows a cyclic behaviour. In most of the time within the cycle this intertidal flat is lowering due to erosion, when it is separated from the sand shoal north of it by a channel. Data analysis shows that this has also been the case during the last decades and also at present (2010): the Smeriggat channel separates the Engelsmanplaat from the Rif in the north. So it is normal that erosion takes place on the Engelsmanplaat lowering this intertidal flat. However, two possible disturbances of the development of the Rif-Engelsmanplaat complex are identified. First, the closure of the Smeriggat and thus the merge of the Rif with the Engelsmanplaat seem to be delayed. Second, the erosion rate on the Engelsmanplaat may be higher than normal.

Two human interferences in the Frisian Inlet have been identified, which possibly have influence on the mentioned disturbances of the morphological development, viz. the closure of the Lauwerszee in 1969 and the gas mining causing land subsidence since 1986. These two interferences are evaluated using process-based modeling. The closure of the Lauwerszee appears to have noticeable influence on the water level in the surrounding of the Smeriggat and substantial influence on the tidal flow velocity in the in the Zoutkamperlaag channel. The change in water level can have influence on the development of the connecting channel Smeriggat. The decrease of the flow velocity in the channel can have decreased the sediment transport from the channel to the intertidal flat, favouring for erosion on the flat. Therefore it is concluded that the closure of the Lauwerszee can have delayed the merging between the Rif and the Engelsmanplaat and it can have accelerated the erosion on the Engelsmanplaat. The land subsidence due to gas mining has much less influence on the hydrodynamic processes. It has no noticeable influence on the water level in the surrounding of the Smeriggat and the bed shear stress under combined action of flow and waves on the Engelsmanplaat. It causes a small increase of the flow velocity in the channel, which should result into sedimentation rather than erosion on the intertidal flat. Therefore it is concluded that the identified disturbances of the development of the Rif-Engelsmanplaat cannot be explained as the effects of the land subsidence due to gas mining.

\section{REFERNCES}

Dastgheib, A., J.A. Roelvink and Z.B. Wang, 2008, Long-term Process-based Morphological Modeling of the Marsdiep Tidal Basin, Marine Geology, doi:10.1016/j.margeo.2008.10.003

De Bok, C., 2001, Long-term morphology of the Eastern Scheldt, Werkdocument RIKZ/2002.108x.

Hayes, M.O., 1979, Barrier island morphology as a function of tidal and wave regime, in Leatherman, S.P. (ed.), Barrier Islands from Golf of Lawrence to the Golf of Mexico, Acad. Press, New York, pp 1-27.

Hibma A, de Vriend H.J, Stive M.J.F. 2003, Numerical modelling of shoal pattern formation in wellmixed elongated estuaries. Estuar. Coast. Shelf Sci. 57:981-91.

Mulder, J.P.M. and T. Louters, 1994, Changes in basin geomorphology after implementation of the Oosterschelde estuary project, Hydrobiologia, 282/283: 29-39.

Oost, A.P., 1995, Dynamics and sedimentary development of the Dutch Wadden Sea with emphasis on the Frisian Inlet, A study of the barrier islands, ebb-tidal deltas inlets and drainage basins, Doctoral thesis, Utrecht University.

Stein, R.C., 1991, Some considerations on tidal inlets, A literature survey on hydrodynamic and morphodynamic characteristics of tidal inlets with special attention to "Het Friesche Zeegat", Report H840.45, WL | Delft Hydraulics.

Van der Wegen, M., Z.B. Wang, H.H.G. Savenije and J.A. Roelvink, 2008, Long-term morphodynamic evolution and energy dissipation in a coastal plain, tidal embayment, Journal of geophysical Research, Vol. 113, F03001, doi:10.1029/2007JF000898,2008.

Van Goor, M.A., M.J.F. Stive, Z.B. Wang, T.J. Zitman, 2003, Impact of sea level rise on the morphological stability of tidal inlets, Marine Geology, Volume 202, issues 3-4, pp.211-227.

Van Veen J. 2005 (1950). Ebb and flood channel systems in the Netherlands tidal waters. J. Coast. Res. 21: 107-120

Wang, Z.B., Louters, T. and H.J. de Vriend, 1995, Morphodynamic modelling for a tidal inlet in the Wadden Sea, Marine Geology, 126 (1995), 289-300.

Wang, Z.B. en W.D. Eysink, 2005, Abiotische effecten van bodemdaling in de Waddenzee door gaswinning, Rapport Z3995, WL | Delft Hydraulics. 